\section{Prof. Szent-Györgyi}

ProF. Szent-Györgyi, the well-known Hungarian biochemist and Nobel prize-winner, has recently visited Moscow at the invitation of the Soviet Government. On May 17, he lectured to the Physiological Society at the University of Moscow on his new work on the chemical composition of striated muscle (Acta Physiol. Skan., 9, Suppl. 25 ; 1945). From muscle material Szent-Györgyi has succeeded in preparing myosin in a crystalline form, and a new protein, isolated by his collaborator, F. B. Straub, called actin. Both myosin and actin have striking properties. Myosin is completely discharged by minimal quantities of potassium. Actin can exist in both globular and fibrous forms, and in the cycle of contraction both forms are involved. The contractile system consists of a combination of these two proteins : actomyosin. In relaxed muscle actomyosin is dissociated into actin and myosin. Actomyosin passes into the contracted form in the presence of potassium, magnesium and adenosin triphosphate. Szent-Györgyi has demonstrated the contractile properties of this system in vitro, and his work provides a mechanical picture which is consistent with all the phenomena of muscle contraction. It is only necessary to assume that in striated muscle there are double rods of actin and myosin, to account for the contraction of living muscle. If the molecules of myosin are spirally arranged around a chain of actin molecules, then contraction, when myosin is discharged by ions, will result in a sudden decrease in the pitch of the spiral. This theory is consistent with microscopic evidence. The familiar cross-striation can be explained by the optical properties of the spiral : for, by rotating muscle fibre under the microscope, Szent-Györgyi has observed the apparent travelling of the spiral along the length of the muscle. This work was done by Szent-Györgyi in Szeged between 1939 and 1944. When the Germans occupied Hungary in 1944, Szent-Györgyi had to go into hiding, and he took a lead in anti-Fascist activities and preparations for the liberation of Hungary. In February 1945 he was liberated by the Red Army. He has now transferred his laboratory to Budapest, and he has accepted chairmanship of the Hungarian Board of Education. Outside his field of research, Szent-Györgyi's main interests are the re-education of his nation for peace, and the re-establishment of international scientific relations.

\section{Prof. Ragnar Granit}

ON June 29, Prof. Ragnar Granit is to deliver at the Royal Institution the fourteenth Thomas Young Oration of the Physical Society, and his subject will be "The Electro-physiological Analysis of the Fundamental Problem of Colour Reception". The occasion will provide an opportunity for a first-hand account of Prof. Granit's recent studies of the electrical response of the retina, summaries of which appeared in Nature of January 2, 1943, p. 11, and June 16, 1945, p. 711. Some fifteen years ago, Prof. Granit was working at the Johnson Foundation of Medical Physics, University of Pennsylvania, on the general problem of the retina as a nervous centre; in these experiments he relied mainly on the subjective observations of flicker phenomena. Later, he worked in Sir Charles Sherrington's laboratory at Oxford, where he investigated and analysed the retinal action potentials which develop on stimulation of the retina by light; in this work his tests were carried out on the retinæ of decerebrated cats. Since then he has held the chair of physiology at the University of Helskinki and is now at the Nobel Institute of Neurophysiology, Karolinska Institutet, Stockholm. The continued refinement of his experimental technique has enabled him to record the responses from individual receptors in the retina and to investigate their variation with wave-length. This work is of fundamental importance to the understanding of the processes of colour perception. The account of Granit's methods is of interest not only in connexion with vision but also in the much wider field of nerve physiology; indeed his studies of the retina now form only a part of his research activities.

\section{Manchester Joint Research Council}

THE Manchester Joint Research Council, which is representative of the University of Manchester and the Manchester Chamber of Commerce, has appointed Mr. A. D. Butchart to be executive officer. Mr. Butchart will commence his duties immediately and will be known as Executive Liaison Officer. As the permanent official of the Council, his duties will cover a wide field; in particular, he will be accessible for discussion and will deal with correspondence having specific reference to any problems facing industrialists where scientific information would prove valuable. It will be recalled that one of the objects of the Council is "the encouragement of activities designed to bring science and industry into closer relationship". As a practical move to give effect to this, the Council is creating an Information Service, and Mr. Butchart will be in charge of it. The service will not aim at furnishing scientific answers to problems submitted, but at placing the inquirer in touch with that scientific institution or authority best able to deal with each particular subject. In short, the essenee of the service will be to introduce the industrial inquirer to the relevant scientific worker. Mr. Butchart has had a long experience in the oil industry. As a research chemist and in other capacities he has served in Burma, Iran and Iraq. From the outbreak of war to the present time, he has been employed on important Government work. Until a permanent office can be established, contact can be made with the Executive Liaison Officer, c/o The Manchester Joint Research Council, at the Manchester Chamber of Commerce, Ship Canal House, King Street, Manchester, 2.

\section{Scholarships and Research Fellowships in the Textile Industries}

Textile Machinery Makers, Ltw., the constituent firms of which are Platt Brothers and Co., Ltd., Howard and Bullough, Ltd., and other textile machinery manufacturers, have established a scheme for the furtherance of higher education and research in relation to the textile industries. It provides in the first instance for the expenditure of $£ 35,000$ over a period of seven years, the administration of the funds being vested in a Board of Trustees for the award of scholarships and research fellowships to be known as "The Sir Walter Preston Scholarships and Research Fellowships" and tenable in the Faculty of Technology of the University of Manchester, or in such other university institution as may be from time to time determined.

The scholarship awards will be as follows : Group I, for works apprentices who have obtained the Higher National Certificate in Mechanical Engineering (£250- 